\title{
ELT with specific regard to Humanistic Approach
}

\author{
Prabhavathy.P ${ }^{1}$, Dr.S.N.Mahalakshmi ${ }^{2}$ \\ '(Research Scholar English, Bharathiar University, India) \\ ${ }^{2}$ (Humanities and Science, Anna University of Technology, India)
}

\begin{abstract}
By learning a language we acquire knowledge and absorb facts about the language. Correspondingly, its experiential emphasis refers as much to awareness of emotional feelings as to direct, active involvement in real contexts of learning. Such attributions and self-efficacy beliefs may work in both positive and negative ways. This paper is intended for practicing teachers as well as for the future teachers. A brief overview of the importance of the use of appropriate methodologies like 'The Silent way', 'Community Language learning', 'Suggestopaedia' and 'Total Physical Response' involving in Humanistic Approach of language teaching and learning at college level includes several strategies such as drafting reports and proposals, language games and puzzles, small-group work, role-play, content-based instruction, cultural and global awareness, etc.,
\end{abstract}

Keywords- Humanistic Approach, Language, Methodologies, strategies, Teaching and Learning

\section{INTRODUCTION}

Other research traditions in psychology and education underline the importance of taking into account and catering for learners' motivation, various findings in social psychology show how values permeate psychological processes, often quite unconsciously. Particularly as a result of previous alternative practices and lack of opportunity for active autonomous engagement, learners' resistance to the uncertainty and threats of freedom and autonomy may be considerable, requiring subtle and well- coordinated strategies carried out over a period of time.

This emphasis on first-order motivational satisfaction has its echoes in otherwise rather different theories. The same doubtless applies to teachers and their motivation to try methods which change their role heavily in the classroom environment. The humanistic approach is one which has been advocated by Mario Rinvolucri for many years. Humanistic approach is the latest and most thought-provoking language-teaching method [3]. The methodologies being discussed under the humanistic approaches were almost all developed by people outside the language-teaching profession. Humanistic "theories" of learning tend to be highly valuedriven and hence more like prescriptions (about what ought to happen) rather than descriptions (of what does happen). It emphasizes the "natural desire" of everyone to learn.

So the teacher relinquishes a great deal of authority and becomes a facilitator. From 1970s, humanism in education has attracted more and more people's attention. According to its theories, the receiver in education is first a human being, then a learner. If a person cannot satisfy his basic needs physically and psychologically, he will surely fail to concentrate on his language learning whole-heartedly. Affect is not only the basic needs of human body, but also the condition and premise of the other physical and psychological activities. So language learning and the affect are closely connected and have aroused many theoretical educators' interests to do research in this field. $[1,4]$

1. Humanistic Methodologies:-

\section{HEADINGS}

The humanistic approach tends to see language learning as a process which engages the whole person and not just the intellect. It takes into account the emotional and spiritual needs of an ilndividual too. The four methods which are generally considered to reflect the philosophy of thehumanistic approach in the fullest measure is explained below:-

1.1 The Silent Way: - his was evolved by Caleb Gattengo, a mathematician. This method uses Fidel charts etc., the teacher is just a facilitator and speaks very little.

1.2 Community Language Learning:-This method was proposed by Charles Curran, a priest, psychologist and counselor who wanted learning to take place in an anxiety-free atmosphere. He proposed that the teacher take an unobtrusive role and just aid the learners to learn the language. The learners form a community, and they help each other to learn the target language.

1.3 Suggestopaedia:-This method was developed by George Lazanov of Bulgaria. As he was a psychiatrist, he used a suggestion as an anxiety-reducing and barrier-removing tool. His classes include fine arts (especially music) as an integral part of the lesson. The functional aspect of the target language is emphasized.

1.4 Total Physical Response:-This was evolved by James Asher, an experimental psychologist, who believed that much of the way in which a child learnt the mother tongue could be duplicated in a foreign language 
situation. His method consists of commands which are followed by learners - learners do not speak until they are ready too. [1]

An explosion of new and radical approaches to learning a language came to light in the 1970s. These methodologies are often grouped under the title of Humanistic Approach of language teaching due to their method of concentration, touching on the innate ability and capacity that all learners are presumed to possess.

\section{Practices in the classroom:-}

Posters, charts, music are used as aids. The classroom usually has comfortable chairs, in which learners can relax. Learners are asked to close their eyes and do some relaxation exercises (like breathing exercises). Learners are given new identities. They are either delegate at a conference; tourists are people trying to get a role in a play or film. Some introductory work is done by a teacher who uses mime and actions to briefly sketch out the new identities of the learners. Next, a dialogue, based on functions, is distributed. The dialogue is in two columns - one column having the dialogue in the target language and the other having the translation in the mother tongue of the learner. There are also some comments in the mother tongue about the use of certain vocabulary items and grammatical structures in the dialogue.

Questions are asked in the target langue about the dialogue. Some translation work too is done. Learners do peer work using the same technique. After this, other activities will be done: games, role play, creative language work, etc. Active participation helps in the learning of new material. Role play (fantasy) reduces threat and so barriers to learning can be overcome.

The above mentioned activities are some of the practices of four humanistic methodologies which can be performed among the learners of language skills in the classroom atmosphere. One of the strongest reasons for supporting humanistic education is that, when done effectively, students learn language very effectively.

\section{RESULTS}

The methods which had been practiced for two semesters (duration of six months each) in the first year of B.E/ B.Tech programme (academic year - 2011 -2012) in Coimbatore district, India was found that the students/learners underwent the greatest metamorphosis in their abilities to independently interact in English during the first semester. Whereas, in the second semester their initial reactions to the courses, pronunciation, evaluation of student/learner progress, the link between input and acquisition, teacher silence and the cultivation of communicative confidence and their performance etc., were analyzed in the form of sample questionnaire and rated accordingly. The results were found to be very effective and also enhanced the spirit of motivation in teaching and learning a language skill humanistically. [Researcher]

\section{CONCLUSION}

To conclude, studies also show that humanistic education can lead to fewer discipline problems in and out of the classroom interactions. The results do show that humanistic education is a valid educational approach that deserves serious attention and respect. This means that humanistic language teachers need to have a thorough grasp of both how people learn and what motivates them to learn. The atmosphere, the material, methods and techniques should aim at 'infantilization' so that learners have a childlike (open-minded) attitude to learning.

\section{REFERENCES}

Books:-

[1] Nagaraj Geetha, English Language Teaching Approaches, Methods and Techniques $2^{\text {nd }}$ (Ed) Orient Blackswan Private Limited, 2010.5567

[2] Krashen, Stephen D, Practical applications of research Psycholinguistic Research ACTFL yearbook Lincolnwood, Illinois' National textbook, 1983.

Web Resources:-

[3] http://www.lotofessays.com/viewpaper/1682820.html

[4] http://www.tjtaylor.net/english/teaching-method-humanistic-techniques 